\title{
THE TECTONOSTRATIGRAPHY OF CYCLADIC BLUESCHIST UNIT ON SIKINOS AND SIFNOS: IMPLICATION FOR THE MESOZOIC TECTONIC SETTING
}

\author{
Papadopoulou S. ${ }^{1}$, Aravadinou E. ${ }^{1}$, Karavoulia C. ${ }^{1}$ and Xypolias P. ${ }^{1}$ \\ ${ }^{1}$ University of Patras, Department of Geology, 26500, Patras, Greece, \\ s.v.papadopoulou@gmail.com,aravantinoue@upatras.gr,p.xypolias@upatras.gr
}

\begin{abstract}
This study presents new results for the tectonostratigraphic configuration of the Cycladic Blueschist unit (CBU) in the islands of Sikinos and Sifnos. These results show that the observed tectonostratigraphy in $C B U$ results from tectonic repetitions of a thinner sequence. Tectonic repetitions have been achieved by a series of largescale ductile thrusts that operated during burial and exhumation of CBU. Restoration of the tectonostratigraphy in both islands implies an original, pre-metamorphic sequence, which was made up by a volcano-sedimentary complex at the base and an overlying carbonate-rich sedimentary succession. This Mesozoic protolithic sequence was possibly formed in a continental terrane or in a transitional domain between a continental terrane and an oceanic basin. We suggest that the Mesozoic protolith of the $C B U$ was formed in an incipient oceanic basin rather than a mature ocean like Pindos Ocean. This incipient oceanic basin was developed either along south part or along the north margin of Pelagonian microcontinent.
\end{abstract}

Keywords: Ductile thrust, Incipient Ocean, Hellenides.

\section{Пєрі́⿱亠乂 $\psi \eta$}



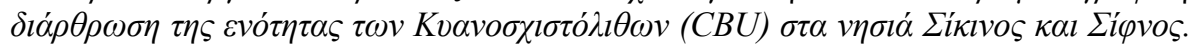

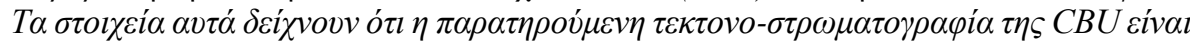

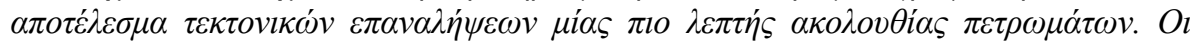

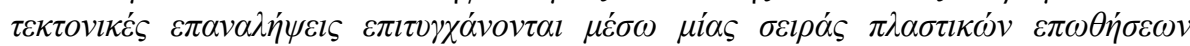

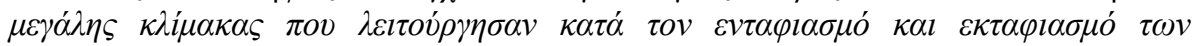

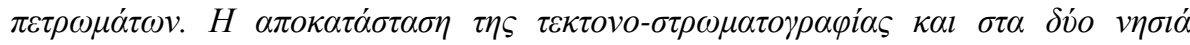

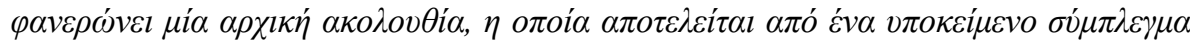

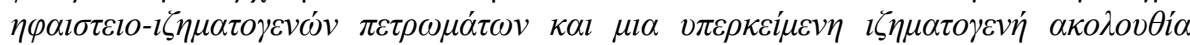

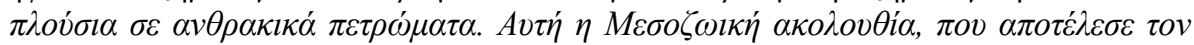

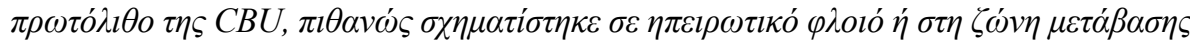

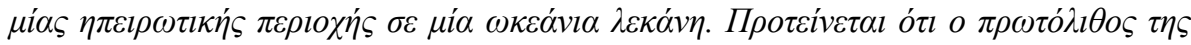

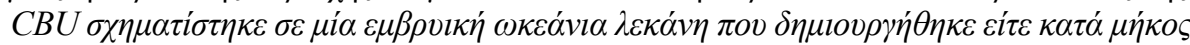

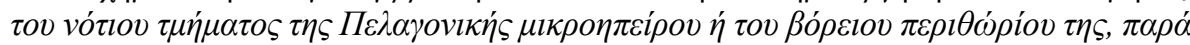

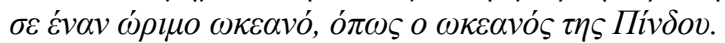

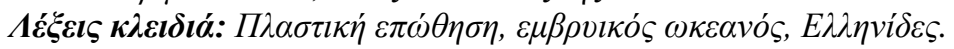




\section{Introduction}

The Cycladic Blueschist Unit (CBU; Fig. 1) is characterized by a complex deformation history, which is expressed by successive generations of ductile structures developed during the Eocene subduction and the subsequent Oligocene-Miocene exhumation of the unit. Subduction-related deformation is mainly manifested by ductile thrusting that led to the formation of individual nappe stacks within the CBU (e.g, Aravadinou et al., 2016). Ductile deformation during the exhumation is represented by thrust-sense shear zones (Xypolias et al., 2012), kilometre-scale folds (e.g., Xypolias and Alsop, 2014) and large-scale extensional detachments (Jolivet and Brun, 2010). Therefore, it is clear, that these large-scale syn-metamorphic structures have significantly modified the premetamorphic stratigraphy of the Permo-Mesozoic protolithic sequence of the CBU, which was dominated by carbonate and pelitic rocks as well as volcanic rocks (Papanikolaou, 2013). Several studies suggest that the protolithic sequence of the CBU was formed in a Permo-Mesozoic passive continental margin (e.g., Dürr, 1986; Okrusch and Bröcker, 1990) whilst the geochemical signature of (meta-) magmatic rocks on Syros and Sifnos can be fitted into a tectonic setting, which encompasses the evolution of an island-arc to a back-arc basin (Mocek, 2001). According to some authors (Keiter et al., 2011) the occurrence of meta-ultrabasites also implies that at least an incipient oceanic lithosphere was occupying the depocentre of the protolithic sequence of the CBU.

Critical for the distinction between different tectonic models is the knowledge of the original premetamorphic stratigraphy of the CBU. However, this requires at least mapping of the zones of tectonic repetition and restoration of the observed tectonostratigraphy. In this work, we provide data for the tectonostratigraphy of CBU on Sikinos and Sifnos Islands and describe the pre-metamorphic succession of the CBU in these islands. The implications of these results are discussed in the frame of the Mesozoic tectonic evolution of Hellenides in Cycladic area.

\section{Geological Setting}

The Cycladic Massif and its structurally overlying Pelagonian Zone were juxtaposed during the Alpine orogeny forming a NW-striking belt in the Internal Hellenides, which is bordered by two major ophiolitic suture zones, the Pindos suture in the west and the Vardar suture in the east (Fig. 1; inset) (Mountrakis, 1986; Doutsos et al., 1993). Within the Cycladic Massif, the CBU occupies an intermediate structural position (Fig. 1b). It is overlain by the Uppermost unit (Okrusch and Bröcker, 1990) and, in turn, is tectonically emplaced over either a crystalline complex of pre-Alpine rocks (Cycladic basement; e.g., Franz et al., 1993), or the Basal unit via a major ductile thrust (Fig. 1a, b; Xypolias et al., 2003).

\subsection{Geology of Sikinos}

The rocks exposed on Sikinos are divided in two distinct tectonometamorphic units, the Cycladic Basement that crops out at the southeastern part of the island and the overlying CBU (Fig. 2b) (van der Maar and Jansen, 1983; Franz et al., 1993; Photiades and Keay, 2003; Gupta and Bickle, 2004). The Cycladic Basement is mainly consisting of orthogneisses and garnet-mica schists, and is characterized by a metamorphic history, which includes a Hercynian amphibolite-facies and two Alpine metamorphic episodes (glaucophane/eclogite-facies metamorphism and greenschist-facies retrogression) (Franz et al., 1993).

Cycladic Basement rocks are tectonically overlain by the CBU. According to Photiades and Keay (2003) the CBU on Sikinos is made up by six district tectonostratigraphic horizons, which from bottom to top are (Fig. 2b): (a) calcite marbles, (b) schists with intercalations of cipolin marble and metabasic lenses, (c) lower dolomite marbles, (d) glaucophane schists with lenses of cipolin marbles and metabasites, (e) alternations of marbles and schists with small lenses of ultramafic rocks and (f) upper dolomite marbles. These rocks have suffered blueschist facies metamorphism $(\mathrm{P} \approx 11 \mathrm{kbar}, \mathrm{T}$ $\approx 475^{\circ} \mathrm{C}$ ) of Eocene age followed by a greenschist facies overprint at the Oligocene-Miocene boundary $\left(\mathrm{P} \approx 5-7 \mathrm{kbar}, \mathrm{T} \approx 380-420^{\circ} \mathrm{C}\right.$ ) (van der Maar and Jansen, 1983; Gupta and Bickle, 2004). 
Deformation history includes three phases of ductile deformation (D1- D3) (Gupta and Bickle, 2004). The D1 produced a S1 foliation parallel to compositional layering. Tight to isoclinal folding of S1 about N-S trending axes during the D2 deformation event, gave rise to a prominent L2 lineation and S2 foliation defined by the orientation of glaucophane and epidote (Gupta and Bickle, 2004; Augier et al., 2015). The D3 deformation is expressed by the development of S-C fabrics and was accompanied by greenschist facies retrogression. All ductile fabrics have overprinted by open cylindrical folds and high angle normal faults. Top-to-the-south thrusting that emplaced the CBU over the Cycladic Basement possibly occurred at the prograde metamorphic stage during D1 and D2 deformation (Gupta and Bickle, 2004). Ductile thrust contact was possibly reactivated as an Ndirected extensional detachment during D3 (Augier et al., 2015).

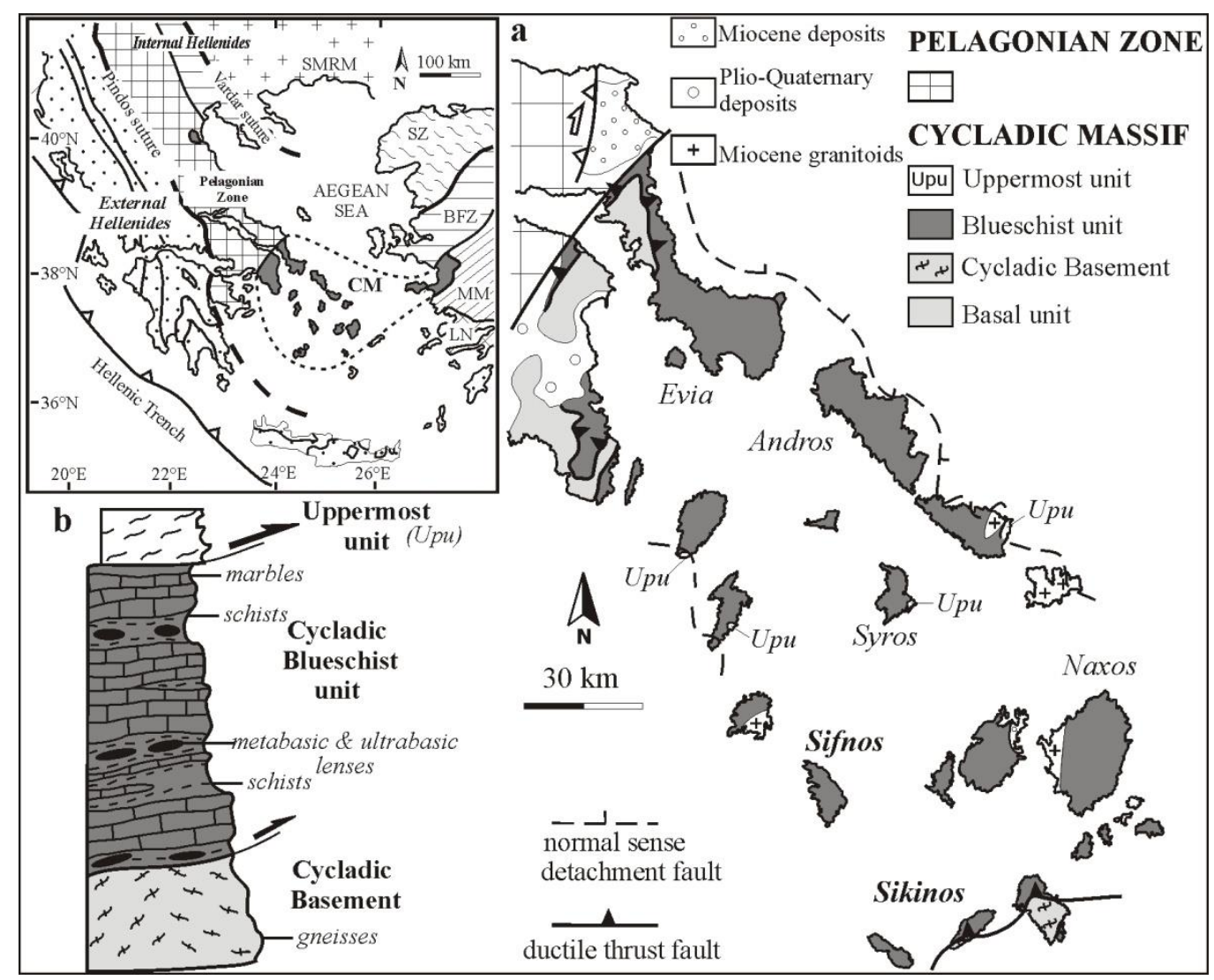

Figure 1 - (a) Simplified geological map of the central-western part of the Cycladic Massif, (b) Tectonostratigraphic column showing the main units of the Cycladic Massif (modified after Okrusch and Bröcker 1990). Inset: Simplified geological map of the Aegean region (CM: Cycladic Massif; BFZ: Bornova Flysch Zone; LN: Lycian Nappes; MM: Menderes Massif; SZ: Sakarya Zone; SMRM: Serbomacedonian and Rhodope Massifs).

\subsection{Geology of Sifnos}

The rocks of Sifnos island belong to the CBU and represent a ca. 2500m thick metamorphic pile which is subdivided, from structurally highest to lowest, into four subunits (Fig. 2a) (Davis, 1966; Matthews and Schliestedt, 1984; Avigad, 1993). (a) The Upper Marble subunit mainly consists of calcite and dolomite marble. (b) The Eclogite-Blueschist subunit represents a meta-volcanosedimentary sequence, which is characterized by alternating basic and felsic metavolcanic rocks (glaucophanites-eclogites and jadeite-quartz gneisses, respectively) and interlayers of metasediments (i.e., mica schists, calcite schists, quartzites). (c) The Main Marble subunit comprises 
chiefly calcite marbles with local schist intercalations. Recently, Aravadinou et al. (2016) unified the Upper and the Main marble subunit into a single subunit. (d) The Greenschist subunit is built up by a meta-volcano-sedimentary assemblage equivalent to those of the Eclogite-Blueschist subunit and consists of metasediments, metabasites and metaacidites of middle Triassic protolith age (Bröcker and Pidgeon, 2007). This rock assemblage has been widely transformed into greenschists facies rocks. Several P-T paths have been proposed for the metamorphic evolution of Sifnos Island. The peak of Eocene HP-metamorphism has been estimated at $450^{\circ}-550^{\circ} \mathrm{C}$ and $12-20 \mathrm{kbar}$ while the $\mathrm{P}-\mathrm{T}$ conditions of Oligo-Miocene greenschist-facies retrogression have been estimated at $350^{\circ}$ $450^{\circ} \mathrm{C}$ and 6-9 kbar (e.g., Schmadicke and Will, 2003).

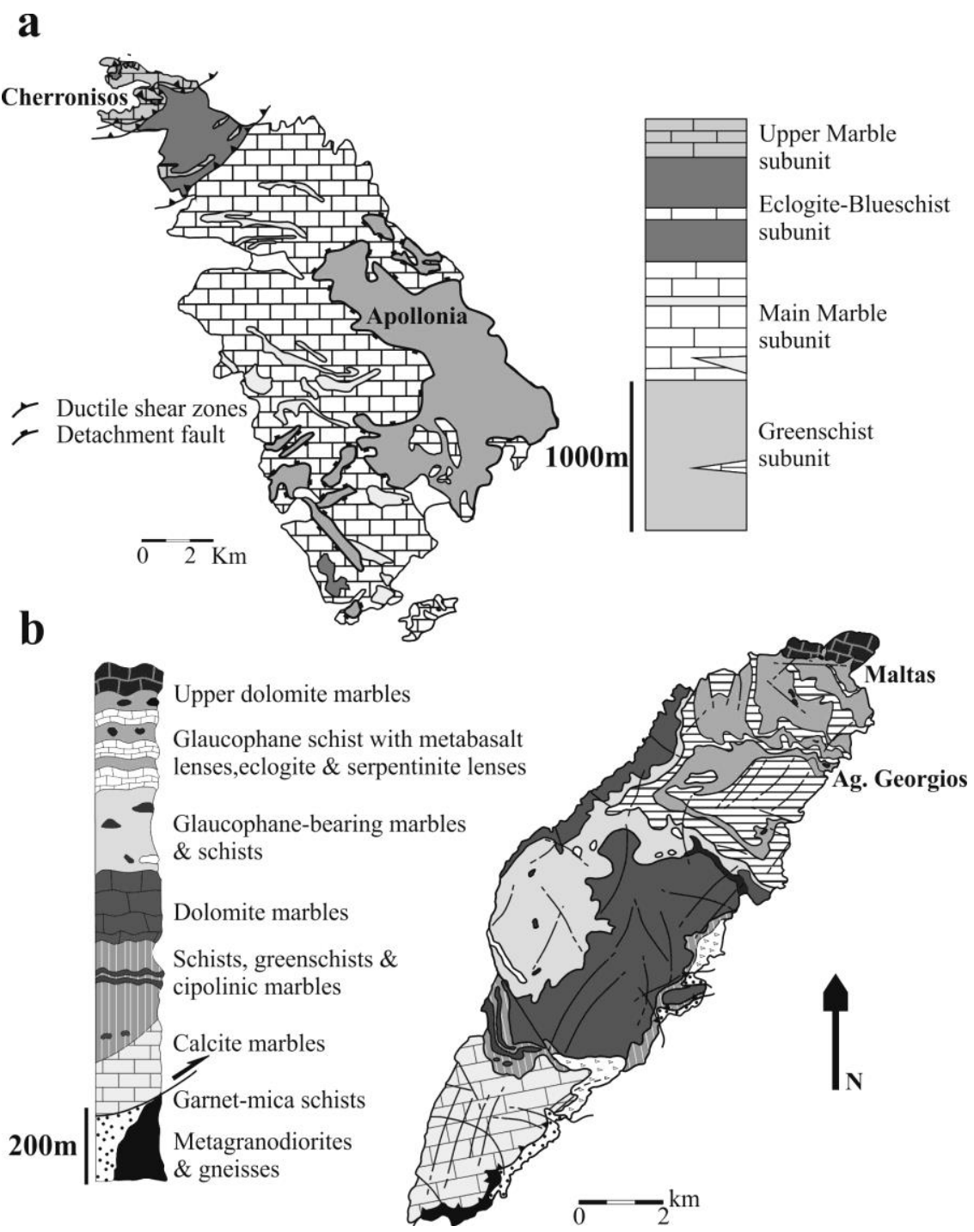

Figure 2 - Geological map and tectonostratigraphic columns of CBU for (a) Sifnos (modified after Avigad, 1993; Aravadinou et al., 2016) and (b) Sikinos islands (after Photiades and Keay, 2003).

In terms of deformation history, three phases of ductile deformation have been distinguished (D1D3) (Lister and Raouzaios, 1996; Aravadinou et al., 2016). The D1 phase is sparse and characterized by an S1 foliation, which is presented as internal foliation in garnets or recognized where it wraps around the hinges of isoclinal, intrafolial folds. The D2 phase occurred at the prograde metamorphic 
stage and is characterized by ESE-directed ductile thrusting that emplaced meta-volcanosedimentary rocks over marbles. The D3 represents the main deformation phase and is manifested by a penetrative S3 foliation and a NE-trending L3 lineation associated with top-to-the-NE sense of shear. Additionally, this phase is represented by outcrop- to map-scale cylindrical F3 folds, with NE- trending axes, parallel to L3 lineation. During D3 deformation, the early D2 thrust contact was folded by F3 recumbent to gently inclined folds, which are genetically associated with thrust-sense shear zones. On south Sifnos, the contact between Main marble subunit and Greenschist subunit is considered to be a brittle extensional detachment but with limited displacement (Avigad, 1993, Ring et al., 2011).

\section{Results}

\subsection{Tectonostratigraphy of CBU on Sikinos}

Based on new field observations on Sikinos, we have distinguished four main lithological subunits within the CBU, which from structurally lowest to highest are: (a) the Meta-Volcano-Sedimentary (MVS) subunit (b) the Dolomite Marbles subunit, (c) the Schists subunit and the (d) Calcite Marbles subunit. The MVS subunit mainly consists of epidotites, epidote-chlorite schists and acidic orthogneisses while locally are observed intercalations of glaucophane schists and quartzites. This subunit is resulted from the metamorphism of a rock complex dominated by basic and felsic volcanic rocks as well as clastic sediments. All rock types in MVS subunit display a well-developed, foliation defined by the shape preferred orientation of blue amphibole, chlorite, epidote, actinolite, white mica and quartz. The Dolomite Marbles are mainly massive and display light grey to white tints. Intercalations of calcite marbles occur throughout the subunit but the dolomite/calcite proportion is, in average, higher than $3 / 1$. The Schists subunit is characterized by alternating mica-schists, chloriteschists, calcite-schists and albite-quartz schist, which exhibit an intensely developed foliation. Minor intercalations of marbles are mainly observed at the lower and the upper tectonostratigraphic levels of the subunit. It should be noted that dolomite marbles intercalations occur typically at the lower levels whilst calcite marbles occur at the upper levels. Possibly this subunit has been resulted from metamorphism of pelitic and clastic sedimentary rocks with minor amounts of carbonate rocks. The Calcite Marbles are strongly foliated and mainly exhibit a grey-blue colour; although white calcite marbles are locally observed. Schist intercalations are quite common at the deeper levels of the subunit. In order to investigate the structural position of the individual subunits of CBU on Sikinos, we constructed three synthetic tectonostratigraphic columns from three different locations in centralnorth Sikinos (Fig. 3).

Specifically, the tectonostratigraphy of CBU on central Sikinos (Bonamas area; Fig. 3A) includes: Calcite Marbles lying over a ca. $70 \mathrm{~m}$ thick package of the Schist subunit which, in turn, overlie ca. $60 \mathrm{~m}$ thick Dolomite Marbles. The latter is underlain by strongly foliated rocks of the MVS subunit (ca. 30m in thickness). In Bonamas area, MVS subunit is tectonically emplaced over mylonitized calcite marbles with schist intercalations, which corresponds to the Calcite Marbles subunit. Therefore, this tectonic contact represents a ductile thrust that duplicates the tectonostratigraphy (Fig. 3A). Mylonites defining this ductile thrust show evidence of extensive greenschist facies retrogression.

In Dialiskari - Ag. Georgios areas, the tectonostratigraphic succession of CBU includes from top to bottom: the Calcite Marbles subunit (ca. 110m in thickness), alternating greenschists and metapelites (ca. 70m in thickness), which belong to Schist subunit, ca. 300m thick Dolomite Marbles and a ca. 40m thick package of the MVS subunit (Fig. 3B). At deeper levels, the rocks of the MVS subunit lying over ca. 50 thick strongly foliated to mylonitic Calcite Marbles, which are underlying by the Schist subunit. The MVS subunit above the Calcite Marbles are strongly deformed exhibiting mylonitic texture and isoclinal-tight folding. Based on this findings, we interpret the contact between the MVS and the Calcite Marble subunit as a ductile thrust zone, which duplicates the original tectonstratigraphic succession (Fig. 3B). Also, it should be noted that the mylonitic texture in MVS 
is defined, among others, by the strong shape preferred orientation of both blue and green amphiboles revealing that mylonitization commenced at deep subduction levels and continued during exhumation of the $\mathrm{CBU}$.

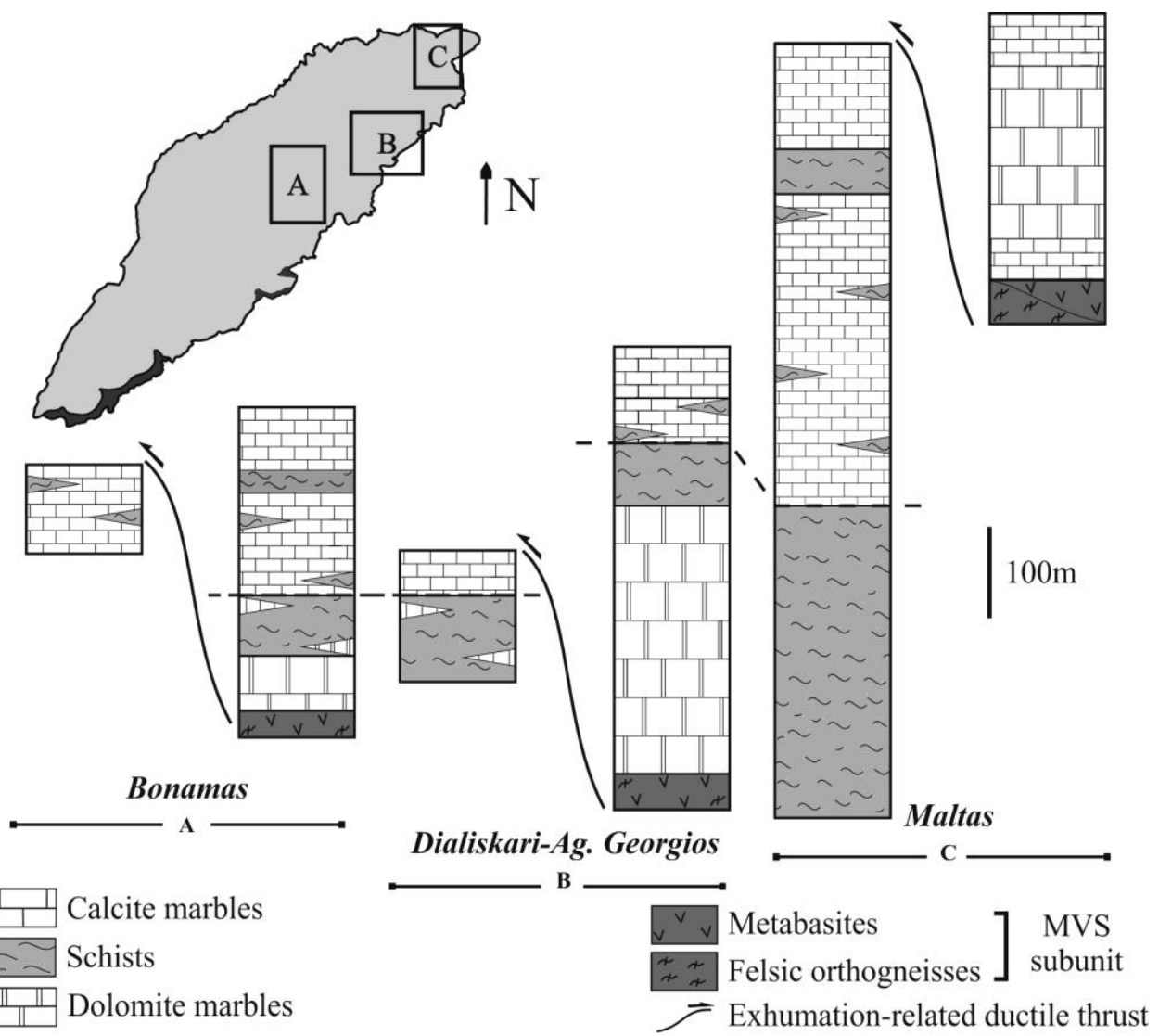

Figure 3 - Tectonostratigraphic columns (A, B, C) showing the structure of CBU in Sikinos. The locations of columns are illustrated on map.

The CBU on north Sikinos (Cape Maltas area; Fig. 3C) is made up of dolomite-calcite marbles alternations (ca. $300 \mathrm{~m}$ in thickness) of Dolomite Marbles subunit, which is underlain by ca. $50 \mathrm{~m}$ thick metavolcanic rocks of the MVS subunit. This rock package is tectonically emplaced over a succession of ca. 520m thick calcite marbles with schist intercalations of Calcite Marbles subunit, which lying over the Schist subunit (ca. 350m in thickness). Along the tectonic contact between MVS and Calcite Marbles subunit, metavolcanic rocks are strongly foliated and display extensive greenschist facies retrogression. Therefore, we interpret the MVS - Calcite Marbles contact as a ductile thrust that duplicated the tectonostratigraphic succession during exhumation of the CBU.

\subsection{Tectonostratigraphy of CBU on Sifnos}

On Sifnos Island we have distinguished two main distinct subunits: (a) the Marble subunit and (b) the Meta-Volcano-Sedimentary (MVS) subunit. The Marble subunit is composed of calcite and dolomite marbles. Calcite marbles are the prominent rock type in the subunit. Calcite marbles are strongly foliated and close to contacts with MVS commonly display a mylonitic fabric. Dolomite marble horizons vary in thickness from few centimetres to several tens of meters. Dolomite marbles are typically massive and display a slight developed foliation near the contact with MVS. Generally, dolomite/calcite proportion increases toward the lower tectonostratigraphic levels of the marble. Also, thin (ca. 1-5m) quartzite intercalations also occur locally. The MVS subunit consists of alternations of basic and felsic metavolcanic rocks as well as by metasediments. The metabasites on 
north Sifnos are represented by glaucophanites and eclogites, while felsic metavolcanic rocks are represented by jadeite-albite gneisses. On the other hand, on south Sifnos, all metavolcanics are strongly retrograded to greenschist facies rocks. Throughout the island, the dominant metasedimentary rocks in MVS subunit are quartz-mica schists and quartzites.
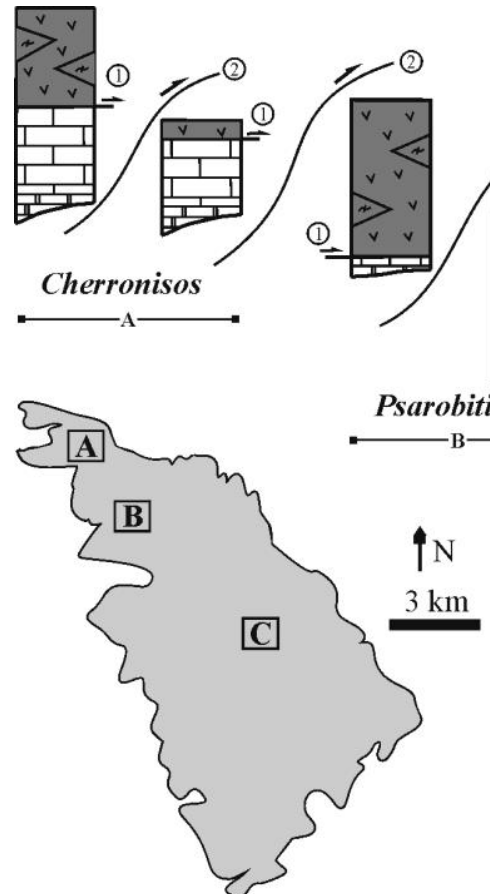
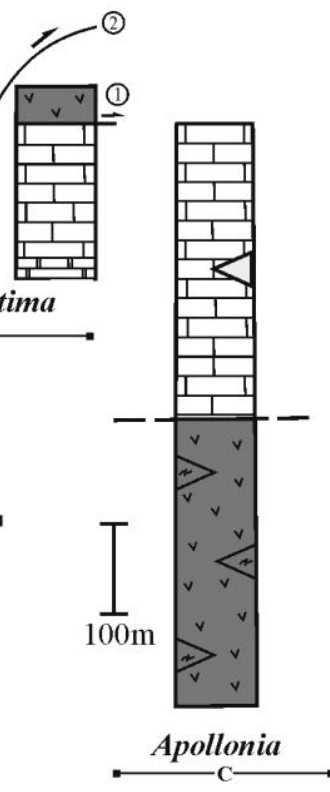

Calcite marbles with schists

嚂四 Dolomite marbles

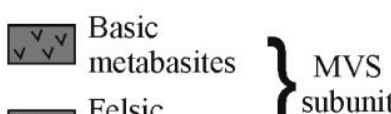

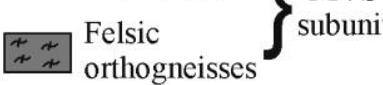

(1) Subduction-related ductile thrust

(2) Exhumation-related ductile thrust

_ - extensional detachment

Figure 4 - Tectonostratigraphic columns (A, B, C) showing the structure of CBU on Sifnos. The locations of columns are illustrated on map.

Concerning the tectonostratigraphy, on south Sifnos (Apollonia area; Fig. 4C), the MVS subunit is overlain by ca. $800-900 \mathrm{~m}$ marbles. It is noted, that the contact between these two subunits is an extensional detachment with limited displacement (Ring et al., 2011), revealing minor disruption of the original stratigraphic succession. On north Sifnos (Cherronisos and Psarobitima areas; Fig. 4A, B), the Marble subunit is overlain by the MVS subunit. This contact is characterized by mylonitized eclogites and glaucophanites revealing that the juxtaposition of these subunits attributed to a ductile thrust that was active during the subduction stage (Aravadinou et al., 2016). In Psarobitima this subduction-related thrust brings ca. $150 \mathrm{~m}$ thick rocks of the MVS over the marble, while in Cherronisos the thickness of the thrusted MVS is ca. 100m (Fig. 4A, B). On north Sifnos, the early tectonostratigraphic succession that was developed during subduction stage is restacked by a series of younger ductile thrusts. These ductile thrusts are defined by mylonitic zones occurring coeval with retrogression of high-pressure parageneses and, therefore, are interpreted as exhumationrelated ductile thrusts. Restacking of the tectonostratigraphy by these thrusts is expressed by the emplacement of marbles over the early established MVS-marble succession (Fig. 4A, B). On north Sifnos, we have recognized three main thrust sheets, which have thicknesses ranging from 200 to $500 \mathrm{~m}$. Within individual thrust sheets the thickness of marbles, which occur at the base, varies significantly (200m in Cherronisos and 50m in Psarobitima; Fig. 4A, B). This difference in marble thickness reveals that ductile thrusts cut across different tectonostratigraphic levels. The restoration of the nappe stack on north Sifnos implies a possibly pre-metamorphic stratigraphic succession in which the protolithic rocks of the MVS subunit are overlain by the protolith of marble subunit. A similar succession is also observed on south Sifnos. 


\section{Discussion and Conclusions}

Our study on Sikinos and Sifnos Islands showed that the observed tectonostratigraphic configuration of $\mathrm{CBU}$ results from tectonic repetitions of a thinner sequence. Tectonic repetitions have been achieved by large-scale ductile thrusts that operated during burial (i.e., north Sifnos) and exhumation of CBU. Restoration of the observed tectonostratigraphy in both islands implies an original, premetamorphic sequence, which was made up by a volcano-sedimentary complex at the bottom and an overlying carbonate-rich sedimentary succession (Fig. 5a). Within this succession the peliticclastic component is significant higher on Sikinos than those on Sifnos where the Marble subunit includes minor intercalations of meta-pelitic/clastic rocks (Fig. 5a). Moreover, the MVS subunit on Sifnos has a thickness of ca. 1000m (Avigad, 1993), while on Sikinos the maximum observed thickness of MVS subunit is ca. 50m. However, it remains unclear whether the thickness of MVS subunit on Sifnos reflects an originally thick volcano-sedimentary complex or is the result of tectonic duplications/repetitions occurring at the base of the stratigraphic pile during subduction and exhumation.

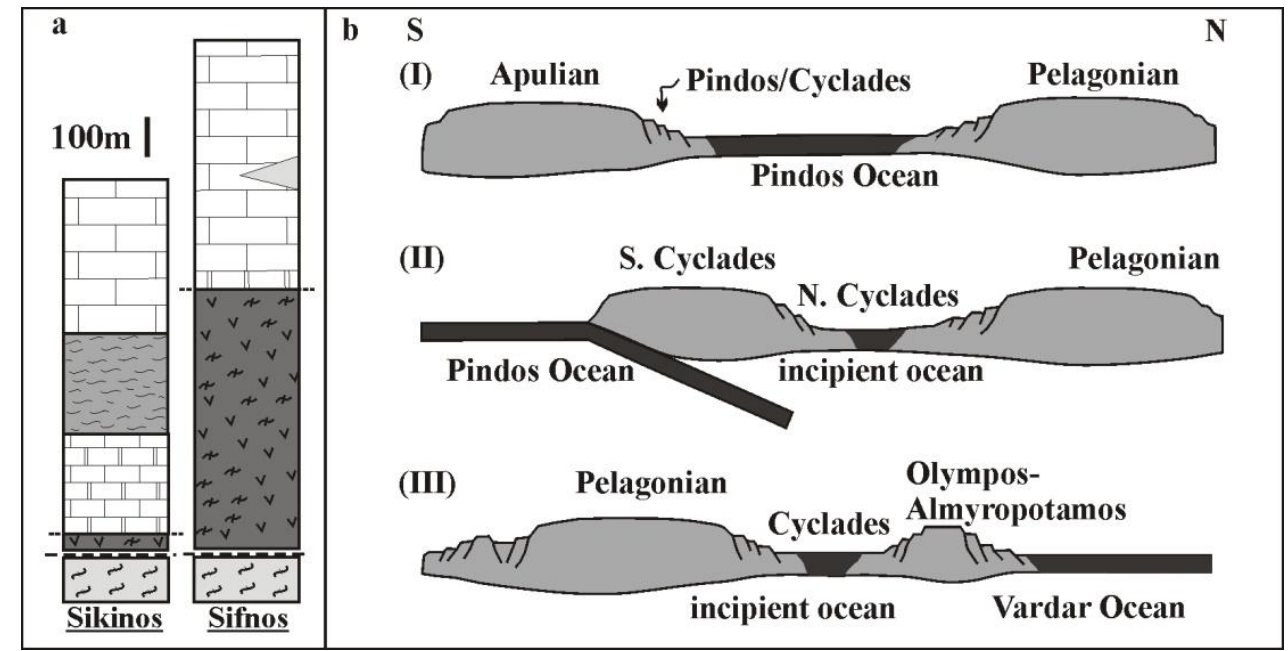

Figure 5 - (a) Stratigraphic columns showing the proposed Mesozoic stratigraphy of CBU's protolith; see Figs. 4, 5 for explanation of symbols). (b) Tectonic models showing the position of CBU's protolith during Late Mesozoic; see text for references.

Isotopic dating data (U-Pb on zircon; Bröcker and Pidgeon, 2007) have yielded Triassic ages (ca. 227-240 Ma) for the magmatic precursors of metavolcanic rocks on Sifnos. These ages coincide with the period of Triassic rifting that have been recorded throughout the Hellenides and resulted to the opening of several Neo-Tethyan oceanic strands in Jurassic (e.g., Robertson et al., 1991). Therefore, it seems that the volcanic rocks of MVS subunit both on Sikinos and Sifnos were erupted in a rift and then overlain by platform carbonates. Possibly, the volcanic activity was absent or very restricted during carbonate sedimentation since marbles show no evidence of intrusions. Limited exposures of metavolcanic rocks in form of outcrop-scale lenses where found in Schist subunit of Sikinos, which possibly reflect a primary association between volcanic and sedimentary rocks.

Based on the two tectonostratigraphic models (continental platforms vs. oceanic basins) proposed by Papanikolaou (2013) for the Hellenides, it seems that the protolithic sequence of CBU on Sikinos and Sifnos resembles more a continental terrane or the transition from a continental terrane to an oceanic basin. In any case, the results presented here do not support the occurrence of a mature oceanic basin as the potential site for the formation of the CBU on Sikinos and Sifnos. However, it should be emphasized that in other islands the CBU shows evidence for larger oceanic component expressed by the presence of metacherts-rich marbles (e.g., Evia; Xypolias et al., 2012) and ultrabasic rocks (e.g., Syros and Tinos; Bulle et al., 2010). Therefore, it is reasonable to assume that 
the original protolithic sequence of CBU on Sikinos and Sifnos were formed along the margin of the rift basin.

However, the position of this rift basin in the Mesozoic palaeogeographic context is a matter of debate and several contrasting models have been proposed. Many studies assume that the CBU is the metamorphic equivalent of Pindos Zone in External Hellenides and therefore suggest that the Mesozoic protolith of the CBU was formed at the south part of the Pindos Ocean (Fig. 5b: I; e.g., Jolivet and Brun, 2010; Papanikolaou 2013). Other studies suggest that the protolith of CBU was formed in a back-arc basin with an incipient ocean crust. This basin was developed along the south part of Pelagonian microcontinent above a north-dipping subduction zone, which is related with the consumption of Pindos Ocean beneath Pelagonian (Fig. 5b: II; Keiter et al., 2011). A third model suggest that the rift basin that hosted the protolith of CBU was situated between the north margin of Pelagonian and the Olympos-Almyropotamos continental fragment (Fig. 5b: III; Doutsos et al., 1993; Xypolias et al., 2003). Note that the latter fragment was separated from Pelagonian forming a narrow basin with an incipient oceanic crust. Tectonostratigraphic data presented here are compatible with the formation of the Mesozoic protolith of the CBU in an incipient oceanic basin (Fig. 5b: II, III) rather than in a mature ocean like Pindos Ocean (Fig. 5b: I). This is also supported by the fact that $\mathrm{U}-\mathrm{Pb}$ zircon ages of $80 \mathrm{Ma}$ from (meta-)gabbroic rocks cropping out on several Cycladic Islands (Bulle et al., 2010), indicate Late Cretaceous basic magmatism, which has not been recorded from the ophiolite complexes related with Pindos Ocean (Dilek et al., 2007). However, more data are required to discriminate between models suggesting an incipient oceanic basin for the formation of the CBU's protolith.

\section{Acknowledgments}

This work was supported by Grant E045 (awarded to P. Xypolias) from the Research Committee of the University of Patras (Programme K. Karatheodori).

\section{References}

Aravadinou, E., Xypolias, P., Chatzaras, P., Iliopoulos, I. and Gerogiannis, N., 2016. Ductile nappe stacking and refolding in the Cycladic Blueschist unit: insights from Sifnos Island (south Aegean Sea), Int. J. Earth Sci., 1-22, doi: 10.1007s00531-015-1255-2.

Augier, R., Jolivet, 1., Gadenne, L., Lahdif, A. and Driussi, O., 2015. Exhumation kinematics of the Cycladic Blueschists Unit and back-arc extension, insight from the southern Cyclades (Sikinos and Folegandros Islands, Greece), Tectonics, 34, 152-185.

Avigad, D., 1993. Tectonic juxtaposition of blueschists and greenschists in Sifnos Island (Aegean Sea)-Implications for the structure of the Cycladic blueschist belt, J. Struct. Geol., 15, 14591469.

Bröcker, M. and Pidgeon, R.T., 2007. Protolith ages of meta-igneous and metatuffaceous rocks from the Cycladic Blueschist Unit, Greece: results of a reconnaissance U-Pb zircon study, J. Geol., 115, 83-98.

Bulle, F., Bröcker, M., Gärtner, C. and Keasling, A., 2010. Geochemistry and geochronology of HP mélanges from Tinos and Andros, Cycladic blueschist belt, Greece, Lithos, 117, 61-81.

Davis, E.N., 1966. Der geologische Bau der Insel Siphnos, Geol. Geophys. Res., Athens, 10, 161-220.

Dilek, Y., Furnes, H. and Shallo, M., 2007. Suprasubduction zone ophiolite formation along the periphery of Mesozoic Gondwana, Gondwana Research, 11, 453-475.

Doutsos, T., Piper, G., Boronkay, K. and Koukouvelas, I., 1993. Kinematics of the Central Hellenides, Tectonics, 12, 936-953.

Dürr, S., 1986. Das Attisch e Kykladische Kristallin, In: Jacobshagen, V., eds., Geologie von Griechenland: Bornträger, Berlin, 116-148.

Franz, L., Okrusch, M. and Brocker, M., 1993. Polymetamorphic evolution of pre-Alpidic basement rocks on the island of Sikinos (Cyclades, Greece), N. Jb. Miner. Mh., 4, 145-162. 
Gupta, S. and Bickle, M.J., 2004. Ductile shearing, hydrous fluid channeling and high-pressure metamorphism along the basement-cover contact on Sikinos, Cyclades, Greece, In: Alsop G.I. et al., eds., Flow Processes in Faults and Shear Zones, Geol. Soc., London, Spec. Publs, 224, 161-175.

Jolivet, L. and Brun, Z.J.P., 2010. Cenozoic geodynamic evolution of the Aegean, Int. J. Earth Sci., 99, 109-138.

Keiter, M., Ballhaus, C. and Tomaschek, F., 2011. A new geological map of the Island of Syros (Aegean Sea, Greece): Implications for lithostratigraphy and structural history of the Cycladic Blueschist Unit, Geol. Soc. Am. Special Paper, 481, 1-43.

Lister, G. and Raouzaios, A., 1996. The tectonic significance of a porphyroblastic blueschist facies overprint during Alpine orogenesis: Sifnos, Aegean Sea, Greece, J. Struct. Geol., 18, 14171435 .

Matthews, A. and Schliestedt, M., 1984. Evolution of the blueschist and greenschist facies rocks of Sifnos, Cyclades, Greece, Contr. Miner. Petrol., 88, 150-163.

Mocek, B., 2001. Geochemical evidence for arc-type volcanism in the Aegean Sea; the blueschist unit of Siphnos, Cyclades (Greece), Lithos, 57, 263-289.

Mountrakis, D., 1986. The Pelagonian Zone in Greece: a polyphase-deformed fragment of the Cimmerian continent and its role in the geotectonic evolution of the eastern Mediterranean, J. Geol., 94, 335-347.

Okrusch, M. and Bröcker, M., 1990. Eclogites associated with high grade blueschists in the Cyclades archipelago, Greece: a review, Eur. J. Mineral., 2, 451-478.

Papanikolaou, D., 2013. Tectonostratigraphic models of the Alpine terranes and subduction history of the Hellenides, Tectonophysics, 595-596, 1-24.

Photiades, A. and Keay, S., 2003. Geological and geochronological data for Sikinos and Folegandros metamorphic units (Cyclades, Greece): Their tectono-stratigraphic significance, Bull. Geol. Soc. Greece, 35, 35-45.

Ring, U., Glodny, J., Will, T.M. and Thomson, S., 2011. Normal faulting on Sifnos and the South Cycladic Detachment System, Aegean Sea, Greece, J. Geol. Soc. London, 168, 751-768.

Robertson, A.H.F., Clift, P.D., Degnan, P.J. and Jones, G., 1991. Palaeogeographic and palaeotectonic evolution of the Eastern Mediterranean Neotethys, Palaeogeogr. Palaeoclimatol. Palaeoecol., 87(1-4), 289-343.

Schmädicke, E. and Will, T.M., 2003. Pressure-temperature evolution of blueschist facies rock from Sifnos, Greece, and implications for the exhumation of high-pressure rocks in the central Aegean, J. Metamorph. Geol., 21, 799-811.

Van Der Maar, P.A. and Jansen, J.B.H., 1983. The geology of the polymetamorphic complex of Ios, Cyclades, Greece, and its significance for the Cycladic Massif, Geol. Rundsch., 72, 283-299.

Xypolias, P. and Alsop, G.I., 2014. Regional flow perturbation folding within an exhumation channel: A case study from the Cycladic Blueschists, J. Struct. Geol., 62,141-155.

Xypolias, P., Iliopoulos, I., Chatzaras, V. and Kokkalas, S., 2012. Subduction- and exhumationrelated structures in the Cycladic Blueschists: Insights from south Evia Island (Aegean region, Greece), Tectonics, 31.

Xypolias, P., Kokkalas, S. and Skourlis, K., 2003. Upward extrusion and subsequent transpression as a possible mechanism for the exhumation of HP/LT rocks in Evia Island (Aegean Sea, Greece), J. Geodyn., 35, 303-332. 